Atıf için / For Citation: E. Arın, E. Önem, M.A Tabur, "Characterization Of Myrrh Essential Oil With GC-MS and Investigation Antibacterial Effects on Salmonella Spp.”, Süleyman Demirel Üniversitesi Fen Edebiyat Fakültesi Fen Dergisi, 16(1), 319-327, 2021.

\title{
Characterization of Myrrh Essential Oil with GC-MS and Investigation Antibacterial Effects on Salmonella spp.
}

\author{
Evren ARIN"1 ${ }^{* 1}$ Ebru ÖNEM ${ }^{2}$, Mehmet Ali TABUR ${ }^{3}$ \\ ${ }^{1}$ Süleyman Demirel University, Vocational School of Health Services, Department of Anesthesia, 32260, \\ Isparta, Türkiye \\ ${ }^{2}$ Süleyman Demirel University Faculty of Pharmacy, Department of Pharmaceutical Microbiology, 32260 \\ Isparta, Türkiye \\ ${ }^{3}$ Süleyman Demirel University, Faculty of Arts \& Sciences, Department of Biology, 32260, Isparta, \\ Türkiye \\ *corresponding authore-mail:evrenarin@sdu.edu.tr
}

(Alınış / Received: 03.01.2021, Kabul / Accepted: 21.04.2021, Yayımlanma / Published: 27.05.2021)

\begin{abstract}
Although Salmonella cause serious infections in animals, they are also of great importance with their zoonotic features. In this study, the antibacterial effects of myrrh (Commiphora myrrha) essential oil on poultry and human isolated Salmonella spp., S. typhimurium ATCC 14028, also Gram-positive (Staphylococcus aureus ATCC 25923, Methicillin Resistant Staphylococcus aureus ATCC 43300), Gram-negative (Pseudomonas aeruginosa ATCC 27853, Escherichia coli ATCC 25922) were investigated agar well diffusion method and minimum inhibition concentrations (MICs) were determined micro dilution methods. In addition bioactive components analysed by gas chromatography-mass spectrophotometer GC / MS. According to the results of GC-MS, major component of myrrh essential oil is curzerene with $24.99 \%$ rate. This was followed by beta elemene with $21.75 \%$. A total of 106 components were detected, and the other components detected were found at between $0.01 \%$ and $1.88 \%$ rate. Antibacterial test result showed that the zone diameter range of essential oil on Salmonella spp. isolates have been determined between $7.75 \mathrm{~mm}$ and $9.75 \mathrm{~mm}$ and MIC values ranging from $12.4 \mu \mathrm{g} / \mathrm{ml}$ to $49.6 \mu \mathrm{g} / \mathrm{ml}$. In reference strains, it was seen that the most effective result was on Gram-positive bacteria.
\end{abstract}

Key words: Antibacterial activity, Curzerene, GC, Commiphora myrrha

\section{Mür Uçucu Yağının GC-MS ile Karakterizasyonu ve Salmonella spp. Üzerine Antibakteriyel Etkilerinin Araştırılması}

Özet: Salmonellalar hayvanlarda ciddi enfeksiyonlara neden olmalarının yanısıra zoonotik özelliklerinden dolayı da oldukça önemlidirler. Yapılan bu çalışma ile mür (Commiphora myrrha) uçucu yağının kanatlı ve insandan izole edilen Salmonella spp. suşları ile $S$. typhimurium ATCC 14028 referans suşu ve Gram-pozitif (Staphylococcus aureus ATCC 25923, Methicillin Resistant Staphylococcus aureus ATCC 43300), Gram-negatif (Pseudomonas aeruginosa ATCC 27853, Escherichia coli ATCC 25922) bazı bakteriler üzerine antibakteriyel etkisi agar kuyucuk difüzyon yöntemi ile araştırılarak minimum inhibisyon konsantrasyonu (MIK) belirlenmiştir. Ayrıca biyoaktif bileşenleri gaz kromotografisi kütle spektrofotometre (GS/MS) ile araştırılmıştır. GS/MS sonuçlarına göre mür uçucu yağının sahip olduğu major bileşen \%24,99 ile curzeren olup \%21,75 ile beta elemenin ikinci major bileşen olduğu görülmüş ve oranları \%0,01 ile \%1,88 arasında değişen toplamda 106 bileşen tespit edilmiştir. 
Agar kuyucuk difüzyon sonuçlarına göre ise Salmonella spp. izolatlatları için tespit edilen zon apları $7.75 \mathrm{~mm}-9,75 \mathrm{~mm}$ aralığında değişkenlik göstermiştir. Mür uçucu yağının izolatlara etki ettiği MiK değeri ise en düşük 12,4 $\mu \mathrm{g} / \mathrm{ml}$, en yüksek $49.6 \mu \mathrm{g} / \mathrm{ml}$ olarak bulunmuştur. Referans suşlarda ise en etkili sonucun Gram pozitif bakteriler üzerinde olduğu görülmüştür.

Anahtar kelimeler: Antibakteriyel aktivite, Curzeren, GC, Commiphora myrrha

\section{Introduction}

Remedy with plants dates back to ancient times and is now used as an alternative treatment option. The therapeutic properties of plants are realized through some molecules in their structures. These substances can be classified as secondary metabolites (terpenes, phenolic compounds, nitrogenous compounds) glycosides, alkaloids, organic acids, tannins, vitamins, carbohydrates and essential oils [1-2]. Especially in recent years, due to the potential dangers of synthetic molecules, the demand for natural ingredients has increased the use of these oils in the food, pharmaceutical, sanitation, perfumery, cosmetics and agriculture sectors [3]. Essential oils have attracted the attention of many scientists due to their wide area of use, and their chemical structures and biological activities have been a matter of curiosity. Essential oils with therapeutic properties are obtained from different parts of the plant such as resin, shell, flower, leaf, seed, root and woody parts [4]. Essential oils obtained from plants or herbal drugs can easily pass through the cell membrane and be easily absorbed from the skin and lungs. In addition to its symptomatic properties such as antitussive diuretic, carminative, cholinetic, it has been shown in studies that it has pain relieving (anti-inflammatory) properties. Nowadays, where antibacterial resistance is a global health threat, essential oils are seen as one of the alternative options in combating infectious diseases and many plant essential oils are the subject of research. There are more than 150 trees and shrubs in the genus Commiphora (Burseraceae), the C. myrrha tree and many other species produce a type of aromatic resin known as myrrh [5]. C. myrrha, referred to as a small tree or large shrub, usually grows in the dry tropical regions of Africa, Arabia and India. The traditional use of Myrrh has been known for the treatment of many diseases from ancient times to date and it is known that it is used for diseases such as gall bladder diseases, chest diseases, fever and stomach complaints, especially in the regions where it grows. It is also used in scorpion stings in India [6]. The name Myrr comes from the Arabic word "pain" "bitter" and is also called Mursafi. It is known that approximately 700,000 people die each year from infections caused by resistant microorganisms, and this number is estimated to reach 10 million a year by 2050 [7].

Salmonella, have the general characteristics of the Enterobactericaea family, cause serious infections in animals, but also have great importance with their zoonotic features [8]. The transmission of S. typhimurium, whose zoonotic agent is well known, from birds to humans has been reported in various studies, especially it has been stated that hygiene rules should be observed when cleaning the litter of birds [9-10].

Salmonella infections in poultry are common worldwide and are very important among foodborne infections [11]. The increase in Salmonella-caused infections in humans and multiple antibiotic resistances in the isolated agents increase the importance of Salmonella in terms of human health. In general, programs to protect human health focus on the control of Salmonella infections during animal production [12]. 
The critical level of resistance to antibiotics has made new strategies to fight against bacteria. The fact that essential oils are subject to a lot of work for their contains and the inability of bacteria to develop mutations against the effects of these molecules make plants attractive [13-16]. With this study, the phytochemical content of myrrh essential oil was tried to be determined and its antibacterial effect on Salmonella spp. were investigated.

\section{Material and Method}

\subsection{Essential oils and GC-MS analysis}

Myrrh essential oil was commercially (ARTdeHUILE) available and its phytochemical contents were determined by GC-MS analysis. GC-MS conditions are shown in Table1.

Table 1. GC/MS analysis conditions

\begin{tabular}{ll}
\hline Column & Cp WAX 52 CB capillary column $(50 \mathrm{~m}$ x 0,32 mm ID, df:1,2 $\mu \mathrm{m})$ \\
\hline Carrier gas & Helium $(99.999 \%)$ \\
Flow rate & 10 p.s.i. \\
Injection volume & $1 \mu \mathrm{l}$ \\
Oven temperature & $60^{\circ} \mathrm{C}$ raised $220^{\circ} \underline{C}^{\prime}$ at $2^{\circ} \mathrm{C} / \mathrm{min}-220^{\circ} \mathrm{C} 20 \mathrm{~min}$ \\
Injection block & $240^{\circ} \mathrm{C}-250^{\circ} \mathrm{C}$ \\
\hline
\end{tabular}

\subsection{Antibacterial activity test}

Nine poultry strains of Salmonella were obtained from Ankara University Faculty of Veterinary Medicine Microbiology Department and clinical isolates were obtained Diyarbakır University Faculty of Medicine Clinical Microbiology Department.

Antibacterial activity of myrrh essential oil was tested using the agar well diffusion method [17]. Overnight cultures of bacteria were prepared according to 0.5 McFarland turbidity. Five ml soft agar (0.5\% agar) with bacterial cultures, added on the Müller-Hinton Agar (MHA) medium and $6 \mathrm{~mm}$ diameter wells were opened on the media. A hundreds microliter of essential oil were added each well. Antibacterial activity was determined by measuring the zone diameters formed after 24 hours of incubation at $35^{\circ} \mathrm{C}$. The test was carried out in triplicate.

\subsection{Minimum inhibitory concentrations (MICs)}

The minimum inhibition concentrations that the essential oil on bacteria have been determined by using the broth dilution method [18]. Cultures prepared by 2-fold dilutions with essential oils in 96-well microplates and left to incubate overnight. At the end of the incubation, $5 \mu \mathrm{l}$ of bacterial cultures were dropped onto the media and left to incubate again at $35^{\circ} \mathrm{C}$ for 24 hours. The next day, MIC values were determined by selecting the lowest concentration in which visible bacterial growth was inhibited in petri dishes, and MIC analysis was performed in 3 replicates. 


\section{Results}

\subsection{GC-MS Analysis}

The components of myrrh essential oil detected by GC / MS are given in Table 2. According to these results, curzerene was the major component with the highest rate of $31.01 \%$. This was followed by beta elemene with $21.75 \%$, ethyl-2,2'-dimethylenebicyclohexyl-3,3' with $11.36 \%$. Other components were followed by the elemene delta with 5.47\%, gamma elemene with $3.59 \%$ and 4,4'-Dimethyl-2,2'dimethylenebicyclohexyl-3,3' diene with $3.90 \%$. A total of 106 components were detected, and the other components were determined between $0.01 \%-1.88 \%$ rate.

Table 2. GC-MS analysis of myrrh essential oil

\begin{tabular}{|c|c|c|}
\hline compound & retention time & $\%$ \\
\hline ethanol ethyl alcohol & 1.383 & 1.77 \\
\hline camphene & 9.468 & 0.06 \\
\hline 2-heptanone 6-methyl & 9.714 & 0.02 \\
\hline 2-furancarboxaldehyde 5-methyl & 9.900 & 0.51 \\
\hline 6-methyl 5-hepten 2 one & 10.159 & 0.06 \\
\hline 2-acetyl 5-methylfuran & 10.300 & 0.02 \\
\hline sabinene & 10.366 & 0.04 \\
\hline 6-methyl-5-hepten-2-one & 10.887 & 0.07 \\
\hline beta myrcene & 11.060 & 0.63 \\
\hline decane n-decane & 11.496 & 0.12 \\
\hline alpha pinene & 11.639 & 0.04 \\
\hline delta 3-carene & 11.743 & 0.05 \\
\hline 3,6-dimethyl 3-octene 2,7-dione & 12.002 & 0.01 \\
\hline * & 12.072 & 0.04 \\
\hline p-cymene & 12.356 & 0.16 \\
\hline trans 2,3-dimethyl bicyclo heptane & 12.546 & 0.01 \\
\hline limonene & 12.681 & 0.56 \\
\hline 1,8 -cineole & 12.760 & 0.11 \\
\hline 2-cyclopenten 1-one 2,3-dimethyl & 12.760 & 0.02 \\
\hline cis ocimene & 12.864 & 0.10 \\
\hline beta ocimene y & 13.279 & 1.55 \\
\hline gamma terpinene & 13.680 & 0.07 \\
\hline benzaldehyde 3-methyl & 14.061 & 0.05 \\
\hline alpha terpinolene & 14.749 & 0.05 \\
\hline benzene (2-methyl 1-propenyl) & 14.919 & 0.04 \\
\hline 3-methyl 2-(2-methyl-2-butenyl) furan & 15.037 & 0.03 \\
\hline p-mentha e- 2,8 dien- 1 & 15.129 & 0.01 \\
\hline furan, 3-(4-methyl-3-pentenyl) & 15.275 & 0.01 \\
\hline hendecane & 15.399 & 0.18 \\
\hline 6-methyl 3,5-heptadien 2-one & 15.475 & 0.05 \\
\hline phenol 2,6-dimethyl & 15.540 & 0.07 \\
\hline 2,4-heptadiene 2,4-dimethyl & 15.819 & 0.01 \\
\hline alloocimene & 16.455 & 0.02 \\
\hline 4-acetyl 1 -methylcyclohexene & 16.503 & 0.03 \\
\hline 2,4,6-octatriene 2,6-dimethyl & 16.906 & 0.08 \\
\hline camphor & 17.114 & 0.01 \\
\hline p-menthan 3-one & 17.474 & 0.08 \\
\hline cyclohexane 1 -methyl 2,4-bis & 17.573 & 0.01 \\
\hline menthofuran & 17.750 & 0.04 \\
\hline 1-menthol & 18.346 & 0.03 \\
\hline 4-terpineol & 18.430 & 0.03 \\
\hline benzaldehyde 2,4-dimethyl & 18.507 & 0.04 \\
\hline 1soxazole 3-carboximidamide & 18.570 & 0.03 \\
\hline beta fenchyl alcohol & 18.989 & 0.03 \\
\hline benzofuran 4,7-dimethylbenzofurar & 19.682 & 0.12 \\
\hline (6-hydroxymethyl-2,3-dimethylphenyl)methanol & 20.241 & 0.03 \\
\hline thymyl methyl ether & 20.607 & 0.01 \\
\hline
\end{tabular}




$$
\text { dispiro undecane 8-methylene }
$$

1h-indene 1,3-dimethyl

bornyl acetate

21.515

0.17

1-menthyl acetate

22.290

0.01

6,7-dimethyl 1,2,3,5,8,8a-hexahydronaphthalene

22.497

0.01 ucyclo hexane 3,3,6,6-tetraethy

22.879

0.01

dehydroaromadendrene

23.215

0.02

p-butoxytoluene

23.786

0.01

elemene delta

23.854

5.47

cyclohexene 4-(1,5-dimethyl-1,4-hexadienyl)-1 -methyl

24.154

0.02

alpha cubebene

0.19

cis-farnesol

24.525

0.03

1,3-dimethyl 3-vinylcyclohexene

24.621

0.03

bicyclogermacrene

24.786

24.942

0.03

ylangene

25.296

0.13

copaene

25.517

0.49

beta bourbonene

25.796

1.93

*

25.896

0.11

beta elemene

26.139

$*$

26.212

0.05

cedrene alpha

26.784

0.05

caryophyllene

27.017

1.67

bergamotol alpha-trans

27.175

0.08

gamma elemene

27.363

3.59

aristolene

27.723

0.03

germacrene $\mathrm{d}$

0.19

isoledene

27.821

0.14

alpha humulene

27.975

0.53

alloaromadendrene

0.16

alpha amorphene

28.330

0.17

gamma cadinene

28.659

0.43

28.829

0.43
1.34

29.130

0.05

*

eudesma-4 11-diene

29.288

1.60

curzerene

29.640

31.01

muurolene alpha

29.689

0.26

delta cadinene

29.800

0.30

29.925

0.09

$*$

30.084

30.237

0.50

*

epizonaren

30.375

0.69

30.440

0.03

gurjunene alpha

boldenone

alpha gurjunene

30.545

30.676

0.08

elemol

31.153

31.507

32.007

32.135

0.19

germacrene $b$

3-methyl 5-methyliden 2-cyclopenten 1-on

0.15

1.88

0.33

0.02

32.692

0.11

germacrone

32.914

33.221

0.00

0.04

33.610

11.36

33.827

3.90

4,4'-dimethyl 2,2'-dimethylenebicyclohexyl 3,3'-diene

33.991

34.360

0.46

34.548

0.14

tetraisopropyliene-cyclobutane

34.757

0.51

0.26

100.00

* unidentified 


\subsection{Antibacterial activity test and MICs}

According to agar well diffusion test results, the widest zone of inhibition value for $S$. aureus ATCC 25923 with $18 \mathrm{~mm}$, followed by MRSA (16mm), S. typhimurium ATCC $14028(10 \mathrm{~mm})$ and E. coli ATCC $25922(9 \mathrm{~mm})$ as shown in Table 3.

Table3. Antibacterial activity and MIC value of myrrh oil $(\mu \mathrm{g} / \mathrm{ml})$

\begin{tabular}{lccc}
\hline & $\begin{array}{c}\text { Zone diameter } \\
(\mathbf{m m})\end{array}$ & $\begin{array}{c}\text { Gentamicin } \\
(\mathbf{1 0} \boldsymbol{\mu} \mathbf{g} / \mathbf{g})\end{array}$ & $\begin{array}{c}\text { MIC value of myrrh } \\
(\boldsymbol{\mu g} / \mathbf{m l})\end{array}$ \\
\hline S. aureus ATCC 25923 & $18 \pm 1,25$ & $14,3 \pm 0,58$ & 6,2 \\
MRSA ATCC 43300 & $16 \pm 1,25$ & $14,30 \pm 0,58$ & 6,2 \\
E. coli ATCC 25922 & $9 \pm 0$ & $18 \pm 0,58$ & 24,8 \\
S. typhimurium ATCC 14028 & $10 \pm 0,58$ & $20 \pm 0,58$ & 49,6 \\
P. aeruginosa ATCC 27853 & - & - & -
\end{tabular}

- no effect

The findings of the strains isolated from humans and poultry, while no antibacterial effect of myrrh essential oil was observed on clinical isolates, values varying between 7$9 \mathrm{~mm}$ were found in strains isolated from poultry Table 4.

Table 4. Antibacterial activity on Salmonella spp. and MIC value of myrrh oil $(\mu \mathrm{g} / \mathrm{ml})$

\begin{tabular}{|c|c|c|c|c|}
\hline & & Zone diameter (mm) & Gentamicin (10 mcg) & $\begin{array}{c}\text { MIC value of myrrh } \\
(\mu \mathrm{g} / \mathrm{ml})\end{array}$ \\
\hline 1 & S 1 & $7,75 \pm 0,58$ & $18 \pm 0,82$ & 24.8 \\
\hline 2 & S 2 & $8 \pm 0,58$ & $11,3 \pm 0,47$ & 12.4 \\
\hline 3 & S 3 & $8,25 \pm 0,58$ & $17,0 \pm 0$ & 12.4 \\
\hline 4 & $\mathrm{~S} 4$ & $8,5 \pm 0,58$ & $20,0 \pm 0$ & 12.4 \\
\hline 5 & S 5 & $8,75 \pm 0,58$ & $18,7 \pm 0,47$ & 12.4 \\
\hline 6 & S 6 & $9 \pm 0,58$ & $18,7 \pm 0,47$ & 24.8 \\
\hline 7 & S 7 & $9,25 \pm 0,58$ & $16 \pm 0,82$ & 49.6 \\
\hline 8 & S 8 & $9,5 \pm 0,58$ & $20,3 \pm 0,47$ & 24.8 \\
\hline 9 & S 9 & $9,75 \pm 0,58$ & $20,7 \pm 0,47$ & 12.4 \\
\hline 10 & SK1 & - & $20,0 \pm 0$ & - \\
\hline 11 & SK2 & - & $20,7 \pm 0,47$ & - \\
\hline 12 & SK3 & - & $19,7 \pm 0,47$ & - \\
\hline 13 & SK4 & - & $20,0 \pm 0$ & - \\
\hline 14 & SK5 & - & $18,7 \pm 0,47$ & - \\
\hline
\end{tabular}

\section{Conclusion and Comment}

The antimicrobial effect of essential oils obtained from various plants against bacteria, fungi and viruses that cause disease in humans has been demonstrated. Studies on the antimicrobial effects of essential oils date back many years, and similar studies are still 
ongoing today [19]. The antimicrobial properties of essential oils are mainly due to the components they have and the amount of major components. Each compound acts against microbes in a different way. Generally, the antibacterial effect occurs as a result of a series of biochemical reactions on the bacterial cell wall depending on the structure of the chemical components in the essential oil [13-14]. In the last few years, gas chromatography mass spectrometry has been an important technological platform for metabolite profiling in both plant species [20]. The determination of the active ingredients contained in plants with the developing technology has resulted in the production of synthetic derivatives as well as their isolation and usage. In this study, according to the GC results of myrrh essential oil, curzerene, a terpenoid, was detected at a rate of $31.01 \%$, while the beta elemene was determined as the second major component with $21.75 \%$. In a similar study, organic components of myrrh were examined and cyclohexanone was found as the major component $(64.66 \%)$, while curzerene was found to be $7.05 \%$ [21]. In another study, two furanoeudesm-1,3-diene isomers $(42.7 \%)$, curzerene $(24.9 \%)$ and $\beta$-elemene $(4.0 \%)$ were detected the major components, respectively [22]. In China, the study which the components of the essential oil isolated from the myrrh plant were analyzed by GC-MS and the presence of monoterpene, sesquiterpene, alcohol and esters was detected, as major components 2cyclohexene-1-one, 4-methyl-4-hydroxy-3,5, 5-trimethyl was found, followed by $\beta$ element, copaen, and aromadaner [23]. The composition of the essential oils that the plants have may vary depending on the largely geographic area age of the plant, drying and extraction methods [24].

Results from the current study show that, when the antibacterial activity of myrrh oil on Salmonella strains isolated from human and poultry, MIC values were found to be the lowest $12.4 \mu \mathrm{g} / \mathrm{ml}$ and the highest $49.6 \mu \mathrm{g} / \mathrm{ml}$ in the strains isolated from poultry, and it was observed that there was no antibacterial effect on strains isolated from humans. Essential oils components have more than one target, therefore, it is difficult to predict how sensitive a microorganism is and why the sensitivity varies from strain to strain [25].

In the literature review, antibacterial studies with myrrh essential oil are very few, and in a study on Gram-positive and Gram-negative bacteria with myrrh essential oil, it was found that it had a high antibacterial effect $(43.2 \mathrm{~mm}$ zone diameter) on the $S$. typhimurium isolated from cheese [26]. Although there are not many studies of myrrh essential oil on Salmonella spp., in a study with Gram negative Pseudomonas aeruginosa, E. coli and Klebsiella pneumoniae strains, different inhibition results were observed for all three bacteria in 5\%v/v concentration [27]. In our study the most antibacterial effect on $S$. aureus with $18 \mathrm{~mm}$ zone diameter and this results followed by MRSA $(16 \mathrm{~mm}), \quad S$. typhimurium $(10 \quad \mathrm{~mm})$, E.coli $(9 \mathrm{~mm})$. Although the antibacterial effects of essential oils are thought to be due to their major component, studies have shown that this is not always the case. For example curzerene is a terpenoid that has antioxidant properties and is known to be effective against diseases related to oxidative damage but terpenes are not a group of ingredients with strong natural antimicrobial activity [20-24].

In summary, antibiotics used in the treatment of bacterial infections have largely lost their effectiveness due to the resistance of bacteria to these antibiotics. As a result, combating infectious diseases has become increasingly difficult, and it has also caused economic losses. The outputs obtained of this study are thought to contribute to researches on the development of new antimicrobial agents that can be used in the fight against bacterial diseases in the medical and agricultural field. Side effects of synthetic 
molecules have also increased the tendency to herbal materials, and as a result, scientific studies on the therapeutic effects of plants and the data obtained are important and it is thought that they may lead new studies.

\section{Author Statement}

Evren ARIN: Investigation, Resource/Material/Instrument Supply

Ebru ÖNEM: Resource/Material/Instrument Supply, Observation

Mehmet Ali TABUR: Supervision, Observation, Advice

\section{Acknowledgment}

As the authors of this study, we would like to thank Ankara University Faculty of Veterinary Medicine Microbiology Department for the poultry isolates used in the study and Diyarbakır University Faculty of Medicine Clinical Microbiology Department for clinical isolates.

\section{Conflict of Interest}

As the authors of this study, we declare that we do not have any conflict of interest statement.

\section{Ethics Committee Approval and Informed Consent}

As the authors of this study, we declare that we do not have any ethics committee approval and/or informed consent statement.

\section{References}

[1] A. Asımgil, "Şifalı bitkiler," Timaş Yayınları, 176 (2), 16-307, 1997.

[2] S. Yaşar, "Determınation of fixed and essential oıl contents and soll characteristic of some perennial medical plants that grow naturally in the campus of Cukurova Unıversity," M.S. thesis, Dept. Bio., Çukurova Univ., Adana, 2005.

[3] W. T. Langeveld., E. J. A. Veldhuizen, and S. A. Burt, "Synergy between essential oil components and antibiotics: a review," Critical Reviews in Microbiology, 40 (1), 76-94, 2014.

[4] A. Başaran, "Natural aromatherapy: herbs \& essences," Turkiye Klinikleri J Med Sci., 29 (5), 86-94, 2009.

[5] S. A. Gadir, and I. M. Ahmed, "Commiphora myrrha and commiphora," Africana essential oils. J. chem. Pharm., 6 (7), 151-156, 2014.

[6] S. Su, T. Wang, T. Chen, J. Duan, L. Yu, and T. Yuping, "Cytotoxicity activity of extracts and compounds from Commiphora myrrha resin against human gynecologic cancer cells," J. Med. Plant Res., 5 (8), 1382-1389, 2011.

[7] M. F. Khan, H. Tang, J. T. Lyles, R. Pineau, Z. R. Mashwani, and C. L. Quave, “Antibacterial properties of medicinal plants from Pakistan against multidrug-resistant ESKAPE pathogens," Front. Pharmacol., 9 (815), 1-17, 2018.

[8] M. Ö. Salar, H. Yardımcı, and K. S. Diker, "Antimicrobial effects of some industrial plants on Salmonella species," Journal of Turkish Veterinary Medical Society., 86 (2), 9-18, 2015.

[9] E. E. Evans, "Zoonotic diseases of common pet birds: psittacine, passerine and columbiform species," Vet Clin North Am Exot Anim Pract., 14, 457-476, 2011.

[10] G. Dinç, M. Doğanay, and M. İzgür, "Important bacterial infections transmitted to humans from pet animals," Turk Hij Tecr Biyol Derg, 72 (2), 163-174, 2015.

[11] M. Akan, "Kanatlilarda salmonella infeksiyonları ve kontrolünde temel prensipler," Mektup Ankara, 6, 3-4, 2008.

[12] A. Kutu, "Isolation, serotyping and investigation of antibiotic susceptrbilities of Salmonella species in poultry," M.S. thesis, Dept. Mic., Adnan Menderes Uni., Aydın, 2017.

[13] M. K. Swamy, M. S. Akhtar, and U. R. Sinniah, "Antimicrobial properties of plant essential oils against human pathogens and their mode of action: an updated review," Evidence-based complementary and alternative medicine., 3012462, 2016.

[14] F. Nazzaro, F. Fratianni, L. De Martino, R. Coppola, and V. De Feo, "Effect of essential oils on pathogenic bacteria," Pharmaceuticals., 6 (12), 1451-74, 2013. 
[15] J.S. Raut, and S. M. Karuppayil, "A status review on the medicinal properties of essential oils," Ind Crops Prod., 62, 250-64, 2014.

[16] D. Trombetta, F. Castelli, M.G. Sarpietro, V. Venuti, M. Cristani, C. Daniele, A. Saija, G. Mazzanti, and G. Bisignano, "Mechanisms of antibacterial action of three monoterpenes," Antimicrob Agents Chemother., 49(6), 2474-2478, 2005.

[17] I. A. Holder, and S. T. Boyce, "Agar well diffusion assay testing of bacterial susceptibility to various antimicrobials in concentrations non-toxic for human cells in culture," Burns., 20 (5), 426-429, 1994.

[18] J. M. Andrews, "Determination of minimum inhibitory concentrations," J. Antimicrob. Chemother., 48 (1), 5-16, 2001.

[19] C. Kürekci, and F. Sakin, "Essential oils:essential oils as antimicrobial: in-vitro and in-vivo studies," Turkiye Klinikleri J Anim Nutr\&Nut., 3 (1), 15-20, 2017.

[20] A. Lytovchenko, R. Beleggia, N. Schauer, T. Isaacson, J. E. Leuendorf, H. Hellmann, J. K. C. Rose, and A. R. Fernie, "Application of GC-MS for the detection of lipophilic compounds in diverse plant tissues," Plant Methods., 5 (4), 2009.

[21] S. R. Ahamad, A. R. Al-Ghadeer, R. Ali, W. Qamar and S. Aljarboa, "Analysis of inorganic and organic constituents of myrrh resin by GC-MS and ICP-MS: An emphasis on medicinal assets," Saudi Pharmaceutical Journal, 25 (5), 788-794, 2017.

[22] J. Zhao, J. Zhang, B. Yang, G.P. Lv, and S. P. Li, "Free radical scavenging activity and characterization of sesquiterpenoids in four species of curcuma using a TLC bioautography assay and GC-MS analysis," Molecules, 15, 7547-7557, 2010.

[23] Y. Chen, C. Zhou, Z. Ge, Y. Liu, W. Feng, S. LI, G. Chen, and T. WeiI, "Composition and potential anticancer activities of essential oils obtained from myrrh and frankincense," Oncol. Lett., 6 (4), 1140-1146, 2013.

[24] C. F. Bagamboula, M. Uyttendaele, and J. Debevere. "Inhibitory effect of thyme and basil essential oils, carvacrol, thymol, estragol, linalool and p-cymene towards Shigella sonnei and S. flexneri," Food Microbiology, 21, 33-42, 2004.

[25] M. Hyldgaard, T. Mygind, and R. Meyer, "Essential oils in food preservation: mode of action, synergies, and interactions with food matrix components," Front. Microbiol., 3 (12), 1-24 2012.

[26] A. G. Mohamed, H. M. Abbas, J. M. Kassem, W. A. Gafour, and A. G. Attalah, "Impact of myrrh essential oil as a highly effective antimicrobial agent in processed cheese spreads," Int. J. Dairy Sci., 11 (2), 41-51, 2016.

[27] N. Khalil, S. Fikry, and O. Salama, "Bactericidal activity of myrrh extracts and two dosage forms against standard bacterial strains and multidrug-resistant clinical isolates with GC/MS profling," AMB Express, 10 (21), 1-10, 2020. 